Г. Н. Степанова

А. С. Филонова

Н. В. Губанова

\title{
2019
}

\section{Развитие интеллектуального}

\section{потенциала личности в XXI веке}

Монография

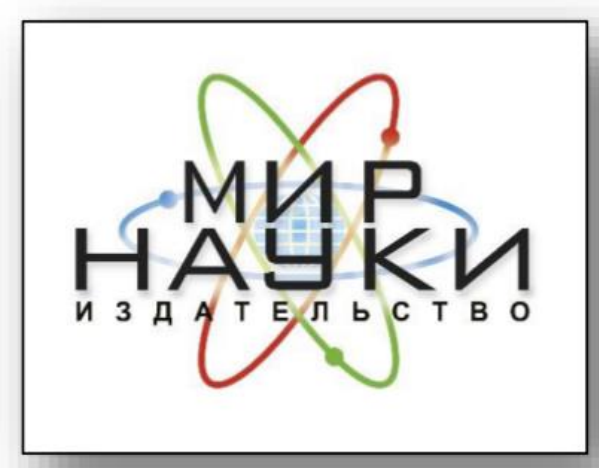




\section{УДК 338:655 \\ ББК 65 \\ C 794}

Рецензент(ы): Никандрова Лариса Константиновна - доктор экономических наук, профессор, ФГБОУ ВО «Российская академия народного хозяйства и государственной службы при Президенте Российской Федерации».

Чванов Роберт Александрович - доктор экономических наук, профессор, ФГБОУ ВО «Российская академия народного хозяйства и государственной службы при Президенте Российской Федерации».

\section{Степанова, Галина Николаевна \\ Филонова, Анна Сергеевна \\ Губанова, Наталья Владимировна}

С 794 Развитие интеллектуального потенциала личности в XXI веке. Монография - М.: Мир науки, 2019. - Режим доступа: https://izd-mn.com/PDF/11MNNPM19.pdf - Загл. с экрана.

ISBN 978-5-6042806-1-4

DOI 10.15862/11MNNPM19

В монографии исследуются проблемы становления личности в информационном обществе. Рассмотрена медиакультура как совокупность интеллектуальных ценностей, выработанных человечеством в процессе исторического развития. Сформулированы предложения по реализации компетентностной парадигмы образования. Монография предназначена для специалистов-управленцев, менеджеров, научных работников, студентов и аспирантов высших учебных заведений.

\section{ISBN 978-5-6042806-1-4}

(C) Степанова Галина Николаевна

(C) Филонова Анна Сергеевна

(C) Губанова Наталья Владимировна

(C) ООО Издательство «Мир науки», 2019 


\section{Оглавление}

Введение............................................................................................ 4

1. Социокультурные аспекты становления личности в информационном обществе 6

2. Экономика знаний и развитие интеллектуального капитала 19

3. Экран - новая метафора эпохи интернета 28

4. Феномен «клипового мышления» в цифровом пространстве 34

5. Кризис идентичности личности в современном мире 39

6. Медиакультура - ключевой фактор формирования общественного сознания 46

7. Образовательные модели формирования интеллектуальной личности .... 54

8. Диалектика творчества как потребности личности 68

9. Когнитивная экономика и креативность персонала .87

10. Концептуальное мышление личности ............................................... 106

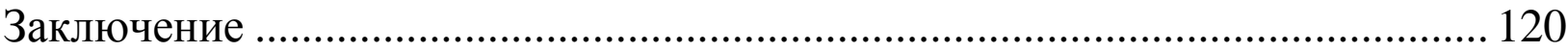

Библиографический список................................................................... 122 


\section{Введение}

Информатизация является важнейшей характеристикой нашего времени. Информатизация общества приобретает глобальный характер, который охватывает различные страны и регионы мира и становится объективной необходимостью.

Нет ни одной области человеческой деятельности, которая не была бы связана с процессами получения и переработки информации.

Цифровые коммуникации представляют собой многомиллиардный рынок, который включает носителей медиа - СМИ, издательства, полиграфия, реклама, компьютерная индустрия, кинематограф, ТВ, сеть Интернет.

Глобальная трансформация индустриальной стадии развития общества в информационную основана на экономике знаний, в которой главным фактором ее развития становится не индустриальный рост, а процесс генерирования, распространения и применения знаний, которые, формируют духовную культуру, идеологию, нравственные принципы, интеллектуальный потенциал человека.

Формирование сетевого общества приведет к качественному изменению социальной структуры общества. В этих изменениях существенное место займет трансформация традиционной культуры в информационную.

Мировую политику сегодня должны определять гуманитарные традиции культуры, духовно-религиозные основы и ценностные ориентиры. Мировому политическому сообществу необходим новый глобальный социокультурный импульс, способный сделать человечество по-настоящему единым перед лицом глобальных вызовов современности.

Именно нравственные ценности могут научить общество воспринимать глобальный мир и уберечь человечество от экологической и нравственной катастроф.

Качественные изменения, связанные с информатизацией общества, определяют не только экономико-социальную и политическую жизнь, но и духовную жизнь общества - моральные ценности и мировоззренческие ориентиры. главным в культуре являются не материальные достижения, а развитие духовно-творческого потенциала личности.

Это задает высокую планку требований $к$ интеллектуальной деятельности, определяет сложный контекст индивидуального роста.

Oсобое внимание уделено медиакультуре как совокупности интеллектуальных ценностей, выработанных человечеством в процессе исторического развития.

Таким образом, при построении стратегии развития России необходимо 
использовать цивилизационную научную парадигму, отстаивающую первенство духовной сферы - науки, культуры, образования, этики.

Ставится задача создания информационно-технологической среды, обеспечивающей переход от псевдоинформационного общества к обществу знаний, в котором истинные знания будут играть решающую роль, а их производство станет определяющим фактором экономического развития.

Цель монографии - выявить особенности развития личности как сложного социокультурного феномена в условиях когнитивной среды XXI века.

Научно-методологической основой монографии являются труды отечественных и зарубежных ученых по глобалистике, информационносетевой экономике, экономике знаний, теории коммуникаций, философии, социологии, культурологии, лингвистике.

Интеллектуальное развитие медиаменеджера вырабатывается в процессе образования, которое позволяет работнику овладеть необходимым набором компетенций.

В условиях когнитивной экономики XXI века будущие специалисты должны изучать современное состояние медиаиндустрии как «индустрии творчества». 


\section{Заключение}

В монографии сформулированы проблемы информационно-сетевого общества и задачи формирования интеллектуального потенциала личности.

Информатизация - объективный процесс общественной эволюции. Этот процесс разворачивается в трех плоскостях - технико-технологическом, социальном и культурном.

Закономерный характер перехода общества к информационной эре обусловлен возрастанием роли знаний в историческом прогрессе. Главным общественным богатством этого общества будет научно-теоретическое знание в форме информации.

Информационная революция качественно изменила технологический базис общественного производства и определила технический аспект информатизации, составляющими которого являются электронизация, медиатизация, компьютеризация и интернетализация.

Социальный аспект информатизации общества заключается в социальной детерминации процесса информатизации общества, а также в воздействии информационных технологий на все сферы общества и способы жизнедеятельности людей.

В социокультурном смысле информационная культура это совокупность принципов, обеспечивающих новые формы связей без личного присутствия в режиме диалога, новый образ жизни на базе использования информации, т.е. построение новой информационной картины мира. В таком контексте информационная культура выступает как способ жизнедеятельности человека в информационном пространстве.

Исследованы тенденции формирования и развития отечественной медиакультры, тренды медиапотребления, медиакультурные факторы трансляции нового социального опыта посредством СМИ.

Важнейшим качеством личности названа медиакомпетентность, а ее формирование - одной из актуальных проблем.

Сформулированы предложения по реализации компетентностной парадигмы образования как основы формирования интеллектуальной личности.

Рассмотрены особенности массовой, информационной, экранной культуры: генезис и основные тенденции развития отечественной медиакультуры.

Особое значение имеет исследование факторов формирования и развития отечественной медиакультуры, позволяющих выявить тренды медиапотребления. 
Изучены медиакультурные тенденции развития форм существования контента. Рассмотрены особенности трансляции нового социального опыта, позволяющие выяснить принципы и правила самоидентификации личности, реализуемые через журнальную периодику.

Медиакомпетентность названа важнейшим качеством личности, а ее формирование - одной из актуальных проблем. Рассмотрены факторы развития современной личности, способной работать с медиатекстом, заниматься медиатворчеством, усваивать новые знания посредством медиа. Сформулированы предложения по развитию медиаобразования как условия всестороннего развития личности.

Доказано, что роль личности как нравственной основы бытия человека в эпоху информатизации усиливается. Многократно возрастают возможности влияния отдельного человека на информационные процессы общества. Это актуализирует у личности сочетание максимальной индивидуальной свободы с высокой мерой ответственности за свои поступки.

Мировоззренческая ориентация личноси - главное требование, предъявляемое к личности эпохи информатизации. Р. Дарендорф пишет: «Чтобы знать направление, индивид должен иметь внутренний компас, а чтобы он работал, снаружи должны быть магнитные поля, позволяющие отличать север от юга, правду от неправды, желательную линию поведения от нежелательной, а также оттенки, находящиеся между этими крайностями». ${ }^{1}$

Эти качества личности должны вырабатываться в процессе образования, которое приобретает качественно новую роль, становится ведущим сектором производства, его «базисом» и движущей силой.

«Образование, - пишет Э. Дайсон, - это тот основной «актив», который требуется человеку, чтобы добиться успеха в мире будущего». ${ }^{2}$ Образование начинается с детства и проходит через всю жизнь, изменяя наши знания и наш духовный мир в соответствии с изменяющимся миром; составной часть этого образования является овладение информационной культурой в ее социальном аспекте.

Условием всестороннего развития личности является медиаобразование. Ставится задача реализации знаниево-предметной и компетентностной концепций образования.

\footnotetext{
1 Дарендорф Р. После 1989. Размышления о революции в Европе. - M.: Ad Marginem, 1998. - С. 175.

2 Дайсон Э. Жизнь в эпоху интернета. - М.: Бизнес и компьютер, 1998. - С. 121.
} 


\section{Библиографический список}

1. А зачем Вам Интернет [Текст] // Пресс-выпуск № 2123. - 09.2012 // www.wciom.ru.

2. Антипов, К. В. Комплекс рекламы в системе общественного воспроизводства: дис. док. экон. наук: 08.00.01 [Текст] / К. В. Антипов. - М., 2009 (Российский государственный социальный университет).

3. Бабицкий, А. Продажная журналистика [Электронный ресурс]. -.Режим доступа: http://www.forbes.ru/tehno-column/budushchee/74713prodazhnaya-zhurnalistika, свободный. - Загл. с экрана. - Яз. рус., англ.

4. Барт, Р. Избранные работы: Семиотика. Поэтика [Текст] / Р. Барт; пер. с англ. - М.: Прогресс, 1994. - 615 с.

5. Батчиков, С. А. Социокультурные основания кризиса, его возможности и угрозы [Текст] / С. А. Батчиков // Экономические стратегии, 2010. - № 12(86). - С. 31 - 33 .

6. Бахтин, М. М. Эстетическое наследие и современность [Текст] / М. М. Бахтин. - Саранск: Мордовский ун-т, 1992. - 167 с.

7. Бахарева, М. В. Использование технологии «учебный портфолио» [Текст] / М. В. Бахарева, Э. В. Никитина, Е.Г. Угольникова // Приложение к журналу среднее профессиональное образование. - 2006. - № 1. - С. 41-45.

8. Беликова, И. Ю. Применение компетентностного подхода при подготовке управленческих кадров малогобизнеса [Текст] / И. Ю. Беликова // Вестник Томского государственного университета - 2012. - № 1(17). - С. 7985.

9. Белл, Д. Грядущее постиндустриальное общество. Опыт социального прогнозирования [Текст] / Д. Белл. - М.: Academia, 1999. - С. 171.

10. Бодрийяр, Ж. Реквием по масс-медиа. Поэтика и политика. Альманах российско-французского центра социологии и философии Института социологии Российской академии наук [Текст] / Ж. Бодрийяр. - М.: Институт экспериментальной социологии. - СПб.: Алетейя, 1999. - С. 193-226.

11. Болонский процесс: нарастающая динамика и многообразие (документы международных форумов и мнения европейских экспертов); под науч. ред. д-ра пед. наук, профессора В.И. Байденко. [Текст] - М.: Исследовательский центр проблем качества подготовки специалистов. - 2002. $-408 \mathrm{c}$.

12. Болотов, Ю. Дополненный киберпанк [Электронный ресурс] -.Режим доступа: http://www.forbes.ru/tehno-column/budushchee/82698dopolnennyi-kiberpank, свободный. - Загл. с экрана. - Яз. рус., англ. 
13. Больц, Н. Азбука медиа [Текст] / Н. Больц; пер. с нем. Л. Ионина, А. Черных. - Москва: Европа, 2011. - 135 с.

14. Бронзино, Л. Ю. Компетентностный подход в образовании: проблема формирования общекультурных компетенций студентов в контексте социокультурной среды вуза [Текст] / Л. Ю. Бронзино, М. Н. Филатова // Современные исследования социальных проблем (электронный научный журнал). - 2012. - № 6 (14).

15. В плену у вампуки [Текст] // «Новая газета». - 2009. - № 4.

16. Ванюшкина, Л. Современный урок МХК [Текст] / Л. Ванюшкина. М.: Чистые пруды, 2007. - 32 с. (Библиотечка «Первого сентября», серия «Искусство». Вып. 6 (18)).

17. Вебер, А. Избранное: Кризис европейской культуры [Текст] / А. Вебер; пер. с нем. - СПб.: Университетская книга, 1998. - 565 с.

18. Вебер, В. Портфолио медиаграмотности [Текст] / В. Вебер; пер. с нем.//Информатика и образование. - 2002. - № 8. - С. 46 - 52.

19. Винтерхофф-Шпурк, П. Медиапсихология. Основные принципы [Текст] / П. Винтерхофф-Шпурк; пер. с нем. О.А. Шипиловой - Харьков: Гуманитарный Центр, 2007. - 288 с.

20. Виртуальная реальность vs реальная жизнь: выбор «интернетчиков. - Пресс-выпуск № 2090. - 08.2012 [Электронный ресурс] -.- Режим доступа: www.wciom.ru, свободный. - Загл. с экрана. - Яз. рус., англ.

21. Газеты, телевидение, радио: стало интереснее, чем два года назад // Пресс-выпуск № 245. - 07.2005 [Электронный ресурс] -.- Режим доступа: www.wciom .ru, свободный. - Загл. с экрана. - Яз. рус., англ.

22. Гендина, Н. И. Информационная грамотность или информационная культура: альтернатива или единство (результаты российских исследований) [Текст] / Н. И. Гендина//Школьная библиотека. - 2005. - № 3. - С.18-24.

23. Глазырина, Л. Д. Основы медиатизации: значение media в социокультурном пространстве [Текст] / Л. Д. Глазырина, С. И. Колбышева // Проблемы управления. - 2009. - № 3 (32). - С. 218 - 222.

24. Голуб, Г. Б. Портфолио в системе педагогической диагностики [Текст] / Г. Б. Голуб, О. В. Чуракова // Школьные технологии. - 2005. - № 1. C. $181-195$.

25. Греф, Г. Учись. Участвуй. Управляй [Текст] / Г. Греф//НГ-Сценарии. Приложение к «Независимой газете». - 02.2012.

26. Дарендорф, Р. После 1989. Размышления о революции в Европе [Текст] / Р. Дарендорф. - М.: Ad Marginem, 1998. - 270 с. 
27. Дайсон, Э. Жизнь в эпоху интернета [Текст] / Э. Дайсон. - М.: Бизнес и компьютер, 1998. - $400 \mathrm{c}$.

28. Дистанционное обучение в СНГ. Тренды развития 2010-2013 [Электронный pecypc] -.- Режим доступа: http://www.smartedu.com/issledovaniya-v-sfere-distantsionnogo-obucheniya/distantsionnoeobuchenie-v-sng.-trendy-razvitiya-2010-2013.html, свободный. - Загл. с экрана. - Яз. рус., англ.

29. Дужникова, А. Анализ контента социальных медиа: вопрос достоверности данных//Инициативный всероссийский опрос ВЦИОМ. 02.2011 [Электронный pecypc] -.- Режим доступа: www.wciom.ru, свободный. - Загл. с экрана. - Яз. рус.. англ.

30. Дужникова, А. Всемирная «барахолка»//Всероссийский центр изучения общественного мнения. - М.: 2011 [Электронный ресурс] -.- Режим доступа: www.wciom.ru, свободный. - Загл. с экрана. - Яз. рус., англ.

31. Дужникова, А. Интернет сегодня//Всероссийский центр изучения общественного мнения - М.: 2012 [Электронный ресурс] -.- Режим доступа: www.wciom .ru, свободный. Загл. с экрана. - Яз. рус., англ.

32. Дужникова, А. Убыточная интернет-торговля: работа над ошибками//Всероссийский центр изучения общественного мнения - М.: 2011 [Электронный ресурc] -.- Режим доступа: www.wciom .ru, свободный. - Загл. с экрана. - Яз. рус., англ.

33. Ежегодный международный доклад «The Millennium Project. Состояние будущего. Перспектива 2011-2050». - М., 2011 [Электронный pecypc] -.- Режим доступа: http://futureview.ru, свободный. - Загл. с экрана. Яз. рус., англ.

34. Журналистские расследования: доверяй, но проверяй?//Еженедельный опрос «ФОМнибус». - 11.2012 [Электронный pecypc] -.- Режим доступа: http://fom.ru, свободный. - Загл. с экрана. - Яз. pус., англ.

35. Загвоздкин, В.К. Роль портфолио в учебном процессе. Некоторые психолого-педагогические аспекты (на основе материалов зарубежных источников) [Текст] / В. К. Загвоздкин//Психологическая наука и образование. - 2004. - № 4. - C. 5-10.

36. Зеленко, Н.В. Портфолио будущего педагога [Текст] / Н. В. Зеленко, А. Г. Могилевская//Стандарты и мониторинг в образовании. - 2009. - № 1. C. 61-63. 
37. Иванов Д.В. Виртуализация общества [Электронный ресурс] -.Режим доступа: http://www.lib.ru/POLITOLOG/ivanov_d_v.txt, свободный. Загл. с экрана. - Яз. рус.. англ.

38. Интернет-банкинг: потенциал развития // Еженедельный опрос «ФОМнибус». - 05.2012 [Электронный ресурс] -.- Режим доступа: http://fin.fom.ru/Finansy/10603, свободный. - Загл. с экрана. - Яз. рус., англ.

39. Калимуллин, Д. Д. Научно-технический прогресс и духовная культура человека [Текст] / Д. Д. Калимуллин//Научно-технический прогресс как фактор развития современной цивилизации: материалы международной научно-практической конференции 15-16 ноября 2011 года - Пенза: Семей: Научно-издательский центр «Социосфера», 2011.

40. Карелов, С. Один ум - хорошо, но два миллиона - лучше [Текст] / С. Карелов // НГ-Сценарии. Приложение к «Независимой газете». - 02. 2012.

41. Кастельс, М. Информационная эпоха. Экономика, общество и культура [Текст] / М. Кастельс; пер. с англ.; под научн. ред. проф. О. И. Шкаратана. - М.: Изд-во ГУ - Высшая школа экономики, 2000. - С. 490.

42. Керс, С. А. Журнал как фактор формирования современной молодежной культуры России. Автореферат диссертации на соискание учен. степ. канд. культурологи, 24.00.01 [Текст] / С. А. Керс. - СПб, 2009. - (Российский государственный педагогический университет им. Л.И. Герцена).

43. Кириллова, Н. Б. Медиакультура: от модерна к постмодерну [Текст] / Н. Б. Кириллова; 2-е изд., перераб. и доп.. - М.: Академический Проект. 2006. -448 c.

44. Кириллова, Н. Б. От медиакультуры к медиалогии // Культурологический журнал. - 2011. - № 4 [Электронный ресурс] -.- Режим доступа: http://www.cr-journal.ru, свободный. - Загл. с экрана. - Яз. рус., англ.

45. Кныш, И. А. Портфель индивидуальных достижений как контрольно-оценочное педагогическое средство [Текст] / И. А. Кныш, И. П. Пастухова//Среднее профессиональное образование. - 2008. - № 1. - С. 69 73.

46. Козловски, П. Культура постмодерна [Текст] / П. Козловски. - М: Республика, 1997. - С. 217.

47. Корнилов, И. К. Развитие управленческого ресурса организации в условиях информационного общества [Текст] / И. К. Корнилов // Известия высших учебных заведений. Проблемы полиграфии и издательского дела. 2011. - № 6. - С. 164. 
48. Курдюмова, И. М. Оценка качества профессионального образования в Великобритании [Текст] / И. М. Курдюмова. - М.: Издательский центр НОУ ИСОМ, 2003. -36 с.

49. Ларионов, И. К. Социальная концепция личности, общества и государства [Текст] / И. К. Ларионов. - М.: Союз, 2000, С. 4-212.

50. Липницкий, А. В. Менеджмент и конфликты [Текст] / А. В. Липницкий//Психология менеджмента. - СПб., 1997.

51. Ломброзо, Ц. Гениальность и помешательство [Текст] / И. Тютюштновой / Ц. Ломброзо; пер. с ит. - М.: Астрель, 2012 - 348 с. - С. 104.

52. Крум, Э. В. Мировой рынок образовательных услуг: тенденции развития, методы регулирования: дис. канд. экон. наук: 08.00.14 [Текст] / Э. В. Крум. - Минск, 2012. - (Учреждение образования «Белорусский государственный экономический университет»).

53. Крылов, А. Н. Эволюция идентичностей: кризис индустриального общества и новое самопознание индивида [Текст] / А. Н. Крылов. - Берлин: West-Ost-Verlag, 2010.

54. Кузьминых, Е. В. Инструменты стратегического планирования ключевых компетенций предприятий полиграфической отрасли. Автореф. канд. дисс. [Текст] / Е. В. Кузьминых. - М., 2006. - С. 5-17.

55. Культурология. ХХ век: энциклопедия. - Т. 1. - [Текст]. - СПб.: Университетская книга; Алетейя, 1998. - 447 с.

56. Куропатов, В. Журналистика широких масс / В. Куропатов // НГСценарии. Приложение к «Независимой газете». - 12.2011. [Электронный pecypc] -.- Режим доступа: http://www.ng.ru/scenario/2011-1227/10_jurnalistika.html, свободный. - Загл. с экрана. - Яз. рус., англ.

57. Левин М. Как технологии изменят образование: пять главных трендов / М. Левин. [Электронный ресурс] -.- Режим доступа: http://www.forbes.ru/tehno/budushchee/82871-kak-tehnologii-izmenyatobrazovanie-pyat-glavnyh-trendov, свободный. - Загл. с экрана. - Яз. рус., англ. 58. Магура, М. И. Современные персонал-технологии [Текст] / М. И. Магура, М. Б. Курбатова. - М.: ЗАО «Бизнес школа «Интернет-синтез»». 2001. - C. 5-376.

59. Маклюэн, М. Понимание медиа: внешние расширения человека [Текст] / М. Маклюэн; пер. с англ. - 2-е изд. - М.: Гиперборея: Кучково поле, 2007. $-462 \mathrm{c}$.

60. Мамардашвили, М. Эстетика мышления [Текст] / М. Мамардашвили. - М: Московская школа политических исследований (МШПИ), 2000. - 416 с. 
61. Маслова, А. В. Виртуальная экономика как проявление виртуализации экономических отношений [Текст] / А. В. Маслова // Век Качества. - 2011. - № 6 .

62. Материалы круглого стола «Неформальное образование: сертификаты и сертификация〉 [Электронный ресурс] -.- Режим доступа: http://management.bel.biz/articles/neformalnoe_obrazovanie, свободный. - Загл. с экрана. - Яз. рус., англ.

63. Маркузе, Г. Одномерный человек [Текст] / Г. Маркузе. - M.: REELbook, 1994. $-344 \mathrm{c}$.

64. Мелюхин, И. С. Информационное общество: истоки, проблемы, тенденции развития [Текст] / И. С. Мелюхин. - М.: Изд-во МГУ, 1999. - 208 с.

65. Мильнер, Б. 3. Управление знаниями: Эволюция и революция в организации [Текст] / Б. 3. Мильнер. - М.: Инфра-М, 2003. - 177 с.

66. Мильнер, Б. 3. Управление знаниями в корпорациях [Текст] / Б. 3. Мильнер, 3. П. Румянцева, В. Г. Смирнова, А. В. Блинникова; под ред. д.э.н., проф. Б. 3. Мильнера. - М.: Дело, 2006. - 304 с.

67. Мирошниченко, А. Река уже изменила русло //«НГ-Сценарии». Приложение к «Независимой газете». - 12.2011 [Электронный ресурс] -.Режим доступа: http://www.ng.ru/scenario/2011-12-27/9_smi.html, свободный. Загл. с экрана. - Яз. рус., англ.

68. Михайлова, Л. Л. Место компетентностного подхода в образовании, его инновационность и традиции [Текст] / Л. Л. Михайлова // Психология в экономике и управлении. - 2010. - № 1 - С. 98-103.

69. Моисеев Н. Слово о научно-технической революции [Текст] / Н. Моисеев. - М.: МГ, 1988. - С. 4-282.

70. Мовсесян А. Современные тенденции становления информационного общества в мировой экономике и России [Текст] / A. Мовсесян//Общество и экономика, 2001. - № 6.

71. Моисеев Н.Н. Расставание с простотой [Текст] / Н. Н. Моисеев. - М.: АГРАФ, 1998. - $473 \mathrm{c}$.

72. Моисеев, Н.Н. Судьба цивилизации. Путь разума [Текст] / Н. Н. Моисеев. - М.: Изд-во МНЭПУ, 1998. - 205 с.

73. Моисеев, Н. Н. Человек и ноосфера [Текст] / Н.Н. Моисеев. - М., 1990, С. 7-302.

74. Муравьев, В. Н. Овладение временем [Текст] / В. Н. Муравьев, Г. Аксенов. - М: РОССПЭН, 1998. - 320 с. 
75. На пути к обществу, основанному на знаниях: из Доклада о развитии человеческого потенциала в Российской Федерации [Текст]//Общество и экономика, 2004. - № 11-12.

76. Негодаев, И. А. На путях к информационному обществу [Текст] / И. А. Негодаев. - Ростов-на-Дону:ДГТУ, 1999. - 247 с.

77. Нестик, Т. А. Развитие культуры обмена знаниями через социальные сети. Лидер-импровизатор: будущее управление проектами [Текст] / Т. А. Нестик. Методические и аналитические материалы Комитета ТПП РФ по деловой этике. - M, 2006. - С. 113-152.

78. Нонаки, И. Компания - создатель знания. Зарождение и развитие инноваций в японских фирмах [Текст] / И. Нонаки, Х. Такеучи; пер. с англ. М.: Олимп-Бизнес, 2003. - 384 с.

79. Огнев, А. Организационное консультирование в стиле коучинг [Текст] / А. Огнев. - СПб.: Речь, 2003. - С. 7-112.

80. Ослон А. Апология умной толпы [Текст] / А. Ослон//НГ-Сценарии. Приложение к «Независимой газете». - 02.2012.

81. Парслоу Э. Коучинг в обучении. Практические методы и техники [Текст] / Э. Парслоу, М. Рэй. - СПб.: Питер, 2003.

82. Петухова С. Аудитория Интернета: вчера, сегодня, завтра//Фонд Общественное мнение. - 10.2012 [Электронный ресурс] -.- Режим доступа: http://runet.fom.ru, свободный. - Загл. с экрана. - Яз. рус., англ.

83. Петухова C. infoБитва: Столицы Vs «другая Россия»//Фонд Общественное мнение. - 07.2012 [Электронный ресурс] -.- Режим доступа: http://runet.fom.ru. - Загл. с экрана. - Яз. рус., англ.

84. Пименова, О. И. Глянцевый журнал как фактор конструирования социально-статусной идентичности молодежи. Автореф. дис. канд. соц. наук [Текст] / О. И. Пименова. - Екатеринбург, 2013. - 28 с.

85. Попов, Е. В. Дифференциация производства новых знаний [Текст] / Е. В. Попов, М. В. Власов//Экономическая наука современной России. Экспресс-выпуск, 2008. - № 1 (13), С. 182-184.

86. Попов, Е. В. Моделирование процессов генерации знания [Текст] / Е. В. Попов, М. В. Власов//Механизм регулирования экономики, 2009. - № 1.

87. Полиектов, В. Исчезнет или возрождается человек в экранной культуре? [Текст] / В. Полиектов. - 1998. - № 10. - С. 3-10 (СанктПетербургский университет).

88. Прохоров, В. Л. Духовно-нравственные приоритеты в воспитании молодежи [Текст] / В. Л. Прохоров//Ученые записки РГСУ. - 2009. - № 6. - С. $6-10$. 
89. Рагулина, Ю. Предпосылки формирования теории и практики управления знаниями [Текст] / Ю. Рагулина//Вестник института экономики РАН. - 2009. - № 2. - С. 193-199.

90. Разлогов, К. Э. Что такое медиаобразование? [Текст] / К. Э. Разлогов//Медиаобразование. - 2005. - № 2. - С. 68-75.

91. Ракитов, А. И. Философия компьютерной революции [Текст] / А. И. Ракитов. - М.: Политиздат, 1991. - 287 с.

92. Российское образование - 2020: модель образования для экономики, основанной на знаниях: к IX Междунар. науч. конф. «Модернизация экономики и глобализация» [Текст]; под ред. Я. Кузьминова, И. Фрумина. М., 1-3 апреля 2008. (Гос. ун-т - Высшая школа экономики. М.: Издат. дом ГУ ВШЭ).

93. Саймон, Г. Скрытые чемпионы (Уроки 500 лучших в мире неизвестных компаний) [Текст] / Г. Саймон; пер. с нем. - М.: Дело, 2005. - 288 c.

94. Самарина, Г. П. Ноосферная экономика: назад к истокам. Базисное значение труда и мотивации [Текст] / Г. П. Самарина, С. К. Дорошко, В. А. Чекирда. - СПб: ПИФ: com, 2008. - 338 с.

95. Самоукина, Н. Коучинг - ваш проводник в мире бизнеса [Текст] / Н. Самоукина, Н. Туркулец. - СПб.: Питер, 2004.

96. Самплер, Дж. Стратегия цифровой эпохи. [Текст] / Дж. Самплер. - В кн.: Файэ Л., Рэнделл Р. Курс МВА по стратегическому менеджменту; пер. с англ. - М.: Альпина Паблишер. 2002, С. 3-478.

97. Сенге, П. М. Пятая дисциплина: искусство и практика самообучающейся организации [Текст] / П. М. Сенге; пер. с англ. - М.: ЗАО «Олимп-Бизнес», 2011. - 448 с.

98. Сафонов, А. Будущее бумажной прессы // Материалы Ежегодного профессионального форума российских издателей «Издательский бизнес Publishing Expo». - 11.2012 [Электронный ресурс] -.- Режим доступа: www.press-expo.ru, свободный. - Загл. с экрана. - Яз. рус., англ.

99. Сергеев, Е. Ю. Средства массовой коммуникации в условиях глобализации // Общество. Среда. Развитие (Terra Humana) [Текст] / Е. Ю. Сергеев. - 2009. - № 1. - С. 126.

100. Соколова, И. В. Социальная информатика и социология проблемы и перспективы взаимосвязи [Текст] / И. В. Соколова. - М.: Союз, 1999. - 228 c.

101. Солдатова, Г. В. Клавиатурный слой//НГ-Сценарии. Приложение к «Независимой газете». - 11.2012. [Электронный ресурс] -.- Режим доступа: 
http://www.ng.ru/scenario/2012-11-27/9_digital.html, свободный. - Загл. с экрана. - Яз. рус., англ.

102. Соломонов, Ю. Хлеб, вода и коммуникация. Интервью с директором Института лингвистики Российского государственного гуманитарного университета М. А. Кронгаузом//НГ-Сценарии. Приложение к «Независимой газете». - 12.2011 [Электронный ресурс] -.- Режим доступа: http://www.ng.ru/scenario/2011-12-27/9_kommunikaciya.html, свободный. Загл. с экрана. - Яз. рус., англ.

103. Сорокин, П. А. Человек, цивилизация, общество [Текст] / П. А. Сорокин. - М.: Политиздат, 1992. - 543 с.

104. Соцсети и мобильный Интернет - взаимный рост и взаимоусиление. - Пресс-выпуск №2020. - 05.2012 [Электронный ресурс] -.- Режим доступа: www.wciom.ru, свободный. - Загл. с экрана. - Яз. рус., англ.

105. Степанова, Г. Н. Интеллектуальная организация: принципы построения и функционирования в экономике знаний XXI века [Текст] / Г. Н. Степанова, Е. Ю. Мастерова //Известия вузов. Проблемы полиграфии и издательского дела, 2011. - № 5. - С. 130-140.

106. Степанова, Г. Н. Управление человеческим капиталом в инновационной экономике: монография [Текст] / Г. Н. Степанова. - М.: МГУП, 2006. - 202 c.

107. Степин, В. С. Теоретическое знание.- М.: Прогресс-Традиция [Текст] / В. С. Степин. - 2003. - 744 с.

108. Стоунхауз Д. Управление организационным знанием [Текст] / Д. Стоунхауз // Менеджмент в России и за рубежом, 1999. - № 1 (16), С. 150-158.

109. Стюарт, Т. А. Интеллектуальный капитал. Новый источник богатства организации [Текст] / Т. А. Стюарт; пер. с англ. - М.: Поколение, 2007. -368 c.

110. Тойнби, А.Дж. Постижение истории: Избранное [Текст] / А. Дж. Тойнби; пер. с англ. Е. Д. Жаркова; под ред. В.И. Уколовой, Д.Э. Харитонова. - М.: Айрис-пресс, 2008. - 638 с.

111. Тоффлер, Э. Третья волна [Текст] / Э. Тоффлер. - М.: АСТ, 2010. $784 \mathrm{c}$.

112. Тоффлер, Э. Шок будущего [Текст] / Э. Тоффлер. - М: АСТ, 2001. - C. 11-207.

113. Тришина, С. В. Информационная компетентность как педагогическая категория [Текст] / С. В. Тришина // Интернет-журнал «Эйдос». - 2005. - 10 сент. http://www.eidos.ru/journal/2005/0910-11.htm. 

293 c.

114. Урсул А. Д. Информация [Текст] / А. Д. Урсул. - М.: Наука, 1971. -

115. Фаэй Л. Курс МВА по стратегическому менеджменту [Текст] / Л. Фаэй, Р. Рэнделл; пер. с англ. - М.: Альпина Паблишер, 2004. - 608 с.

116. Федоров, А. В. Медиакультура: от модерна к постмодерну [Текст]/ А. В. Федоров. - М.: Академическая проспект, 2005. - 448 с.

117. Федоров, А. В. Медиаобразование и медиаграмотность в обществах знаний // ЮНЕСКО между этапами Всемирного саммита по информационному обществу [Текст] / А. В. Федоров. - М.: Изд-во Ин-та развития информационного общества, 2005. - С. 329-339.

118. Фетисов, А. В. Управление культурами [Текст] / А. В. Фетисов. М.: Изд-во «Дело» АНХ, 2010. - 140 с.

119. Фирсов, А. В. Становление креативного менеджмента в условиях информационной экономики XXI века; пер. с англ. [Текст] / А.В. Фирсов//Полиграфист. - 2013. - № 60. - С. 70.

120. Франчук, В. И. Основы современной теории обществ. [Текст] / В. И. Франчук .- М.: Ин-т орг систем, 2001. - С. 70. - (Междунар. акад. орг. наук, Ин-т орг. Систем).

121. Хабермас, Ю. Вовлечение другого [Текст] / Ю. Хабермас; пер. с нем. Ю. С. Медведева; под ред. Д. В. Скляднева. - СПб.: Наука, 2001. - 415 с.

122. Хабермас, Ю. Моральное сознание и коммуникативное действие [Текст] / Ю. Хабермас; пер. с нем.; под ред. Д. В. Скляднева. - СПб.: Наука, 2006. $-377 \mathrm{c}$.

123. Хоркхаймер, М. Диалектика просвещения. Философские фрагменты [Текст] / М. Хоркхаймер, Т. Адорно; пер. с нем. М. Кузнецова М.-СПб: Медиум, Ювента, 1997. - 312 с.

124. Чижевский, А. Л. Физические факторы исторического процесса [Текст] / А. Л. Чижевский. - Калуга: 1-я Госполитография, 1924. - 76 с.

125. Шелдрейк, Дж. Теория менеджмента от тейлоризма до японизации [Текст] / Дж. Шелдрейк. - СПб.: Питер, 2001. - 352 с.

126. Экономика знаний [Текст]; под ред. В.П. Колосова. - М.: ИНФРАM., 2008. - C. 8-35.

127. Шпенглер, О. Закат Европы: очерки морфологии мировой истории [Текст] / О. Шпенглер. -Том.2; пер. с нем. и примеч. И. И. Маханькова- М.: Айрис-пресс. 2004. - 624 с. 


\author{
Степанова Галина Николаевна \\ Филонова Анна Сергеевна \\ Губанова Наталья Владимировна \\ Развитие интеллектуального потенциала личности в XXI веке \\ Монография издана в авторской редакции \\ Главный редактор - Кирсанов К.А. \\ Вёрстка - Кирсанов К.К. \\ Ответственный за выпуск - Алимова Н.К. \\ Научное издание \\ Системные требования:
}

IBM РC с процессором Pentioum 2; О3У 128 Мб; операц. система Windows XP; программа Adobe PDF Reader; CD-ROM дисковод, мышь.

Принято к публикации 13 мая 2019 года.

Режим доступа: https://izd-mn.com/PDF/11MNNPM19.pdf, свободный. - Загл. с экрана. Яз. рус., англ.

ООО «Издательство «Мир науки»

«Publishing company «World of science», LLC

Адрес:

Юридический адрес - 127055, г. Москва, пер. Порядковый, д. 21, офис 401.

Почтовый адрес - 127055, г. Москва, пер. Порядковый, д. 21, офис 401.

https://izd-mn.com

ДАННОЕ ИЗДАНИЕ ПРЕДНАЗНАЧЕНО ИСКЛЮЧИТЕЛЬНО ДЛЯ ПУБЛИКАЦИИ НА ЭЛЕКТРОННЫХ НОСИТЕЛЯХ 